\title{
Perguntas sobre o conservadorismo de José de Alencar
}

\author{
José Quintão de Oliveira*
}

\begin{abstract}
Resumo
Parece não haver entre a crítica literária nacional a mínima dúvida a respeito do conservadorismo de José de Alencar. Desde a sua época, o escritor é apontado como um conservador e algumas vezes mesmo como um escravocrata. Pretende-se analisar essas certezas tão sólidas e definitivas não para decidir sobre a sua correção ou incorreção. A partir de um olhar sobre a carreira e os escritos políticos, as peças teatrais e a ficção de Alencar se quer compreender seu pensamento e convicções. Por essa via talvez se termine por trazer algumas questões e dúvidas a um tema em que parece existir muita certeza e pouco debate.
\end{abstract}

Palavras-chave: José de Alencar. Conservadorismo. Escravismo e literatura.

\section{Introdução}

José de Alencar era um conservador. Se há um tema que não precisa ser debatido é esse. Desde o século 19 se estabeleceu, entre os críticos literários brasileiros e entre os estudiosos da literatura de maneira mais ampla, uma sólida convicção a esse respeito. A grande verdade mesmo é que esse assunto parece realmente dispensar que se debata ou que se argumente em favor da sua afirmação. Basta que se mencione o adjetivo-chave: está mais do que provado, é do geral conhecimento. O escritor era "conservador", aponta Brito Broca (BROCA, 1979, p. 264); "reacionário dos quatro costados", segundo Astrojildo Pereira (PEREIRA, 1944, p. 269). Era ainda "o adversário da emancipação dos escravos", como registrou José Veríssimo (VERÍSSIMO, 1977, p. 80); “de ideias conservadoras”, opinou Mário Merlino (MERLINO, 1984, p. XII); na visão de Francisco de Assis Barbosa era um "conservador, escravista" (BARBOSA, 1977, p. 61). Apontamlhe o conservadorismo, além desses, José Carlos Garbuglio, Silviano Santiago, David Treece e Joaquim Nabuco. Destacam-se esses nomes como exemplo

* Instituto de Estudos Brasileiros da USP, professor de Literatura e pesquisador, desenvolve, no pósdoutorado, estudos sobre a obra de José de Alencar, com bolsa de pesquisa da FAPESP. 
entre incontáveis outros, parte expressiva daqueles que estudaram a sua obra ou simplesmente mencionam autor e obra em seus escritos.

Nas páginas que seguem, essa verdade tão firmemente estabelecida será posta em questão - sua origem, suas bases, seus conteúdos serão analisados e inquiridos. Afinal, de onde surgiram e por que se fixaram essas convicções tão sólidas? Que obras daquele autor fundamentam-nas, dão-lhes substância e garantem que permaneçam durante tão largo período de tempo? O escritor teve uma vida pública de pouco mais de 25 anos; foi conservador durante todo esse tempo ou converteu-se a esse credo em algum momento? Havendo conversão, quando se deu? Essas e muitas outras perguntas que o assunto provoca - ou deveria provocar - merecem ser consideradas; verdade tão sólida precisa ser iluminada pela dúvida e o debate. Questionar a afirmação do conservadorismo do escritor não significa afirmar o oposto, que Alencar não era um conservador. Trata-se de se matizar a questão e se tentar um olhar mais amplo e, se possível, sem juízo prévio. E, antes de tudo, perguntar o que era ser liberal ou conservador no tempo em que viveu, escreveu e fez política. Ainda, considerando-o como conservador, que conservadorismo seria o seu? Não se trata da ideia de uma missão: combater a visão equívoca que se estabeleceu sobre o escritor cearense. Não se intenta defendê-lo, que não precisa ser defendido; tampouco fazerlhe justiça. Longe disso. Na verdade, o que se busca é uma visada nova sobre um tema estabelecido, muito falado e, na verdade, quase nunca discutido, o que, aliás, parece ser justificativa mais que suficiente para se voltar sobre o já dito.

\section{A definição política e partidária}

É comum que se aponte como índice do conservadorismo escravocrata de Alencar o fato de ter atuado politicamente no Partido Conservador. Pergunta-se se hoje seria adequado estabelecer a posição política de uma pessoa tomando por base o nome da agremiação a que pertence. A resposta honesta e leal seria certamente negativa. $\mathrm{Na}$ época se dava a mesmíssima coisa; o que, em linguagem de hoje se expressa na paráfrase da famosa da expressão atribuída ao político Ferreira Viana: nada mais conservador que um liberal no poder; nada mais liberal que um conservador na oposição. Em outra forma: "Era comum ouvir-se dizer, em meados do século passado, não haver nada tão parecido com um saquarema como um luzia no poder." (MATTOS, 1987, p. 103). Traduzindo-se à linguagem atual, tem-se saquarema por conservador e luzia por liberal. Excetuados os momentos de forte exacerbação 
política, como o assassinato de Líbero Badaró, a crise da abdicação de Pedro I, as crises da Regência e do período inicial do reinado do segundo Pedro, encerradas em 1848 com a Revolução Praieira, não havia muita definição das posições políticas.

Deve ser ainda lembrado que as ditas propostas políticas liberais eram normalmente tornadas ações de governo pelos conservadores. O fim definitivo do tráfico de escravos, em 1850, ocorreu sob gabinete conservador; o mesmo se deu com a abolição da escravidão. A proibição da exposição e pregão de escravos aconteceu por determinação do ministro da Justiça, por meio do decreto 1695, de 15 de setembro 1869 , ao mesmo tempo em que vedava também a separação da família escrava pela venda. Ministro conservador de um gabinete conservador, cujo nome não deve ficar omitido: José de Alencar. "Era a conhecida ironia: os liberais propunham as reformas que os conservadores realizavam.” (CARVALHO, 1981, p. 181). Na longa jornada da abolição gradual do trabalho escravo, sob governo liberal foi aprovada a Lei dos Sexagenários; as demais foram votadas, decididas e encaminhadas por gabinetes conservadores, inclusive a abolição definitiva com a chamada Lei Áurea, de 1888.

Observem-se agora os movimentos de algumas figuras de proa da política do Império: Rio Branco de liberal se torna conservador; Nabuco Araújo, Zacarias e Saraiva fazem o percurso inverso, de conservadores se tornaram liberais, com o interlúdio da Frente Progressista. Antônio Paulino Limpo de Abreu, Visconde de Abaeté, foi liberal extremado, estava entre os 23 deputados que se dirigiram a Pedro I no documento que contribuiu para precipitar a Abdicação. Na sua longuíssima carreira política, de extrema importância para o país, ocupou os mais altos postos do Império. Foi inúmeras vezes ministro, deputado, senador, presidente da Província de Minas Gerais e desempenhou importantíssimas missões diplomáticas. E, mais que tudo, será sempre lembrado como o ministro da Justiça que, com tanta energia e desassombro, se opôs à Inglaterra quando da questão da lei Aberdeen. Pois desse excepcional homem público quase se pode dizer que pela manhã, ao sair de casa, precisaria ser lembrado sobre o nome do partido a que estava no momento filiado, tantas vezes mudou de um para outro. Não se vá, porém, imaginar que nas metamorfoses partidárias de Limpo de Abreu - Limpo de Brio, como os chamaram os liberais certa vez entre uma e outra dessas idas e vindas - ou de qualquer outro dos seus pares, tenha ocorrido alguma mudança da posição política. Como já observou Oliveira Viana, 
os partidos políticos do Império, imponentes embora pela sua massa, não tinham propriamente uma opinião; eram simples agregados de clãs organizados para a exploração em comum das vantagens do poder. [...] não representavam realmente correntes de opinião; os programas que ostentavam eram, na verdade, simples rótulos, sem outra significação que a de rótulos. (VIANA, 2006, p. 16).

Assim se compreende por que não ocorreu mudança de posição política de Limpo de Abreu ou de qualquer outro dos que transitavam entre os dois partidos. ${ }^{1}$ Não ocorreu e não era necessária, tal a contiguidade entre os agrupamentos de um e de outro nome. As trocas de ministério praticamente não passavam de revezamento dos membros do grupo dominante no Parlamento, sem nenhuma mudança política significativa. Dizia-se mesmo que os partidos que se revezavam no poder, trocavam as pastas ao entrarem no Ministério; o partido que entrava entregava ao que saía a pasta com o programa da oposição e deste recebia aquela com o programa do governo. Por aí se compreende que a reforma do Judiciário, as eleições diretas, a adoção do sistema métrico, além de todas as leis emancipacionistas do escravismo, excetuada a lei dos Sexagenários, como já dito, bandeiras caras aos liberais, foram realização dos conservadores, contando muitas vezes com aguerrida oposição de alguns liberais. Assim, parece que se pode dizer sem ironia que um verdadeiro liberal, que quisesse realmente tornar efetivo seu programa político, deveria militar nas fileiras conservadoras. Não se avança sobre a posição política dos republicanos pela singela razão de que esses não ocuparam o poder, mas não seriam diferentes dos demais partidos. Disso é exemplo o famoso documento da convenção de Itu, bastando que se leia a parte que trata da escravidão. ${ }^{2}$ Não parece, portanto, complacente a afirmação de que o conservadorismo do escritor deve ser buscado em outra parte; a simples filiação partidária não se mostra suficiente para justificá-la. Talvez se possa fundá-lo melhor analisando-se a posição do autor de Iracema face à então chamada questão servil.

1 "Os dous velhos partidos do Império, como se vê, não tinham opinião, como não tinham programas. O objetivo era a conquista do Poder e, conquistado esse, conservá-lo a todo transe: nada mais. Era este o principal programa dos liberais - como o era dos conservadores.” (VIANA, 2006, p. 19).

2 Oliveira Viana não se guardou da ironia ao comentar o tratamento do assunto pelo documento republicano: "No gênero lusco-fusco, no gênero 'quero não quero', no gênero encruzilhada, é o que há de mais obra-prima. Eis aqui um documento que devia resplandecer em moldura de ouro, nas paredes do Museu de Itu." (VIANA, 2006, p. 66). Doces palavras do sábio monarquista, especialmente quando comparadas ao que disse desses republicanos e do seu manifesto o republicano Júlio Ribeiro em seu livro Cartas sertanejas. 


\section{Ação política e escravismo}

A lei do Ventre Livre foi defendida por liberais como Francisco Otaviano e atacada por outros do mesmo partido, como Zacarias. Como observa José Honório Rodrigues, o próprio Rio Branco afirmou no Congresso que "essa lei na verdade concedia muito à escravidão, e muito pouco à liberdade (RODRIGUES, 1972, p. 8). José de Alencar, que a combatia, defendeu em discurso no Parlamento, ante o silêncio de conservadores e liberais, que a aprová-la seria melhor acabar de vez com a escravidão. A lei, como é do geral conhecimento, foi aprovada em 28 de setembro de 1871, dois meses depois da morte de Castro Alves. Foi então festejada como um grande progresso; o resultado da sua aprovação está muito bem descrito por Nabuco no seu $\mathbf{O}$ abolicionismo. A escravidão, por sua vez, persistiu até a assinatura da lei de 13 de maio, 17 anos depois.

José de Alencar, como já se mostrou, era favorável à abolição que se processasse de forma consensual e planejada, isto é, "gradualmente" (ALENCAR, 1977, p. 197) - é dele o termo. Opunha-se à ruptura se desse irrefletidamente, cujos efeitos, - que considerava mais que possíveis ou prováveis como certos e incontornáveis - sobre a "primeira das nossas indústrias, a agricultura" (ALENCAR, 2011, p. 226), o assustavam. Note-se que os únicos produtos de exportação do país eram originados do grande latifúndio - café, açúcar, basicamente - e esse se apoiava no trabalho escravo. Acrescente-se o permanente descalabro das contas do Império, o verdadeiro "pauperismo do estado" apontado por Uricoechea. Finda a escravidão, que seria do latifúndio? Que seria das exportações? E o que seria do Governo e da administração desse verdadeiro "estado indigente" (URICOECHEA, 1978, p. 155; 304 et passim), cuja arrecadação dependia em 70\% dessa exportação? (CARVALHO, 1981). A importância do latifúndio e, consequentemente do trabalho escravo em que se apoia em dependência quase que absoluta, vinha desde os tempos coloniais, como já se disse e se se vê em Antonil (1976, p. 89): “Os escravos são as mãos e os pés do senhor de engenho; porque sem eles no Brasil não é possível fazer, conservar, aumentar fazenda, nem ter engenho corrente." E o repete quase que com as mesmas palavras Ina von Binzer mais de século e meio depois: "Todo trabalho é realizado pelos pretos, toda riqueza é adquirida por mãos negras" (BINZER,1996, p. 40). Acrescente-se a isso a gigantesca perda patrimonial que representava a abolição da propriedade do escravo, uma vez que este constituía, segundo Faoro (1984), mais de 70\% do capital investido na 
produção de café. ${ }^{3}$ Excetuada a pecuária e a lavoura de subsistência, a produção de outros consumíveis agrícolas, destinados ao mercado interno ou à exportação, o quadro não seria muito diverso uma vez que todos se baseavam no uso intensivo do trabalho escravo. Seria interessante observar o que tem a dizer Celso Furtado que procede a uma análise sucinta e desapaixonada das dificuldades encontradas para o fim do escravismo e observa que:

Constituindo a escravidão no Brasil a base de um sistema de vida secularmente estabelecido, e caracterizando-se o sistema econômico escravista por uma grande estabilidade estrutural, explica-se facilmente que para o homem que integrava esse sistema a abolição do trabalho servil assumisse as proporções de uma "Hecatombe social". (FURTADO, 2000, p. 141).

Os termos entre aspas, que Furtado toma de Alencar, bem traduzem os extremos da sua angústia ante o desconhecido representado pelo fim do trabalho servil e suas consequências. Assim se compreende, como observa Furtado, que mesmo indivíduos lúcidos e essencialmente antiescravistas, como Mauá (1964), se assustassem ante as consequências do fim do sistema escravagista. Tanto quanto se preocupam políticos como Alencar e outros em posição assemelhada, mesmo aqueles que se apresentavam como liberais e abolicionistas, propunham sempre uma solução gradual, protelatória e negociada para o problema. Seria interessante registrar que Ina von Binzer que soube olhar a sociedade brasileira de então com olhos tão críticos e sensíveis, que se entusiasmava com o fim próximo da escravidão, acreditava que esse acontecimento poderia ser realmente catastrófico em várias regiões do país. Joaquim Nabuco (1963) resume bem o espírito da época: "todos pensavam, ou que a abolição arruinaria a lavoura e o crédito do país, ou que o Brasil não era rico bastante para "pagar a libertação moral" do seu território." (NABUCO, 1963, p. 114). Pela expressão destacada, entenda-se indenizar os proprietários de escravos. José Murilo de Carvalho, por sua vez, observa que “o compromisso e a adaptação foram a característica básica da elite política e intelectual, refletindo a situação do país em que um governo constitucional e uma constituição liberal tinha que coexistir com as oligarquias rurais e com o trabalho escravo." (CARVALHO, 1981, p. 70).

3 Diz o estudioso: "no século XIX, [...] o valor dos escravos chegou a alcançar mais de $70 \%$ do conjunto da terra, instalações e construções do estabelecimento cafeeiro." (FAORO, 1984, p. 132). 
Como se vê, a importância econômica do trabalho escravo, a duração da escravidão por um tão largo lapso de tempo e a sua disseminação pela sociedade tornaram a abolição um processo extremamente doloroso. Assim, o seu fim, lento e gradual como se processou, encontrou durante todo o processo resistências quase intransponíveis. Mais de uma vez, os governos conservadores tiveram de tomar atitudes extremamente autoritárias, como a remoção de juízes para avançar alguns poucos passos. De uma feita foram demitidos desembargadores da Relação da Bahia para se obter que da Justiça a sentença condenatória de traficantes detidos em flagrante de tráfico. O mesmo se deu também em Recife onde Eusébio de Queiroz afastou outros três desembargadores. Essa resistência e má vontade que não se limitavam aos fazendeiros e ao judiciário espraiavam-se por outros setores sociais e tinham apoio popular, como registra Murilo de Carvalho (1988). A mesma luta teve de enfrentar o Ministro da Justiça que sucedeu a Queiroz, Nabuco de Araújo, até que se alcançou em 1855 a definitiva extinção do tráfico. Fosse diferente, teria sido muito mais forte e eficaz a pressão social sobre o mundo político pela sua erradicação. Exatamente o que reivindicava o escritor cearense como motor para o movimento do seu partido nesse rumo.

Coerentemente com uma posição política, defendia que os acontecimentos deveriam se precipitar espontaneamente, por sua própria força interna. Ao interferir nesse movimento espontâneo pela via da legislação, acreditava que seria melhor que se o fizesse de maneira definitiva, abolindo de vez a escravidão, como defendeu no Congresso e nos seus escritos políticos. Nas Novas cartas políticas, assinadas por Erasmo, contrapõe ao gradualismo abolicionista "o meio pronto, súbito, instantâneo, como uma calamidade menor. Era uma amputação dolorosa; se o enfermo não sucumbisse, a chaga iria cicatrizando, e ele ficaria mutilado, porém, tranquilo." (ALENCAR, 2009, p. 326).

Consequentemente, descartado o "o meio pronto, súbito, instantâneo", caberia ao Estado ação complementar e secundária, como a emancipação dos escravos com vínculo estatal ou a votação de verbas para a manumissão pelas assembleias provinciais, câmaras municipais e outros atos legislativos que provessem o gradual adoçamento do cativeiro etc. O Partido Conservador, isto é, o seu partido, porém, entendia Alencar, não poderia "fazer reformas precipitadas, não [poderia] votar leis que afetam interesses graves ou princípios cardeais do sistema, quando não sofre a pressão enérgica da opinião, quando não é, por assim dizer, impelido pelo país." (ALENCAR, 1977, p. 203). Esse o papel dos partidários do conservadorismo. 
O partido Liberal, ao contrário, "marcha na vanguarda, aventa as ideias, apontaas à opinião, lança-as na discussão" (ALENCAR, 1977, p. 197), avalia. Com a oposição, sempre, dos conservadores, que não aceitam nada que não esteja bastante amadurecido, define. Estes não tomam a vanguarda, diferentemente daqueles, seguem sempre a reboque da opinião, estabelece. Em discurso no Parlamento em 14 de maio de 1870, pouco depois de se afastar do ministério, esclarece:

Cumpre anotar, porém, Senhores, que eu nunca pretendi que o Partido Conservador fosse escravagista, que o Partido Conservador aceitasse a instituição da escravidão como uma instituição firmada no direito, na moral que deve ser mantida e respeitada. Não, Senhores, o nobre Presidente do Conselho acaba de dizer: "Raros serão os brasileiros - e eu acrescentarei: esses mesmos, cegos pelo interesse ou pelo erro -, raros serão os brasileiros que aceitem a instituição da escravidão como uma instituição legítima. (ALENCAR, 1977, p. 186).

Não parece haver motivos que justifiquem a recusa à afirmação do deputado; não parece haver nada a mostrar que seu discurso esconde algum propósito oculto ou é simplesmente mentiroso. Nas Novas cartas políticas enfatiza que:

A escravidão se apresenta hoje, ao nosso espírito, sob um aspecto repugnante. Esse fato do domínio do homem sobre o homem revolta a dignidade da criatura racional. Sente-se ela rebaixada com a humilhação de seu semelhante. $\mathrm{O}$ cativeiro não pesa unicamente sobre um certo número de indivíduos, mas sobre a humanidade, pois uma porção dela acha-se reduzida ao estado de coisa. (ALENCAR, 2009, p. 283-284). ${ }^{4}$

Cumpre dizer que a posição gradualista era partilhada por todo mundo da política. Era a posição do senador Nabuco Araújo; era a posição do seu filho Joaquim Nabuco, como esse diz no seu Minha formação. Um verdadeiro movimento abolicionista nacional só surge mesmo posteriormente à aprovação da lei dos Sexagenários, até então esse movimento era apenas emancipacionista, ou seja, propugnava-se pela emancipação de alguns escravos a cada momento e de todos ao final de um período relativamente longo. "O meu projeto primitivo, em 1880, era a abolição para 1890 com indenização.” (NABUCO, 1963, p. 114). A abolição seria um passo muito mais radical, pois significaria tornar a escravidão ilegal,

4 A mesma condenação aparece também em A propriedade, obra de 1883, à frente citada. 
procedendo a uma espécie de julgamento moral de uma experiência histórica que remontava praticamente ao alvorecer da ocupação europeia das terras americanas. Só a partir daquela data, dois anos depois da morte de Alencar, se reivindicará a abolição da escravidão, testemunha Nabuco: "Não há muito que se fala no Brasil em abolicionismo e partido abolicionista. [...] Foi na legislatura de 1879-80 que, pela primeira vez, se viu dentro e fora do Parlamento um grupo de homens fazer da emancipação dos escravos [...] a sua bandeira política." (NABUCO, 2000, p. 1).

E essa abolição deveria se dar com o pagamento da devida indenização. Esclareça-se, ao dono do escravo libertado, não a este, como já se viu nas palavras do mesmo Nabuco.

\section{0 monarquista}

José de Alencar - como Joaquim Nabuco, como Taunay, Rio Branco e boa parte da elite política de então, conservadores ou liberais - temia o que poderia resultar do final do regime monárquico. Seu espírito agudo antevia a pólvora e o sangue que essa fatalmente traria para a cena política nacional, como sobejava nos países vizinhos, da Patagônia à fronteira sul dos Estados Unidos. Da "mazorca platina" à "anarquia mexicana" (VIANA, 200, p. 377), usando-se os termos de Oliveira Viana, que diz ainda, em outra parte: "Esta desconfiança da República era, aliás, justa, era explicável, era natural em todos os espíritos sensatos daquele tempo.” E observa que não se podiam ter boas impressões da ideia republicana, pois essas seriam "as impressões da caudilhagem hispano-americana. E, mais especialmente, da caudilhagem platina” (VIANA, 2006, p. 90), que tantos problemas já ocasionara ao Império quanto dores aos seus povos. Nabuco mostra magistralmente algumas dessas razões no seu Balmaceda, livro escrito e publicado ainda na aurora da experiência republicana nacional. Afinal, pode-se perguntar -, quantos não terminaram mortos nessas repúblicas por muito menos que as cartas de Erasmo? Quanto à república norte-americana, julgavam-na uma experiência histórica excessivamente curta para ser tomado como paradigma; temia-se muito que a exuberância da jovem nação redundasse em um fracasso tão grande como aquele que viam nas demais repúblicas do Novo Mundo. Também não era muito entusiasmante para esses espíritos a experiência francesa com seus golpes, contragolpes, revoluções e levantes. Havia medo do futuro e das mudanças prognosticadas para esse futuro. Parece que se tem de reconhecer - havia sólidas razões para isso. 


\section{0 liberalismo libertário de Alencar}

Defensor convicto do habeas corpus, Alencar deve ser apontado como o introdutor da modalidade preventiva no direito brasileiro. Em 1868 impetrou e obteve-a em favor do seu sogro, Thomas Cochrane, quando ainda não estava previsto nas leis do país. Posteriormente a esse feito, foi essa modalidade integrada ao ordenamento jurídico nacional. (Aqui se anota que seria interessante verificar se esse processo foi preservado, o que permitiria conhecer a qualidade da argumentação jurídica sustentada pelo jurista Alencar.) Combateu a eleição censitária, defendendo a igualdade dos eleitores, resumível na fórmula um homem, um voto. Foi durante toda sua vida defensor pertinaz da liberdade de expressão. Ministro da Justiça, tinha à sua disposição os cofres públicos para subsidiar jornais e jornalistas que apoiassem sua política. Nunca o fez. Defendeu também a plena garantia legal ao direito da minoria à representação parlamentar, a chamada democracia proporcional (ALENCAR, 1874).

Araripe Júnior, antes de crítico literário, jurista de notável saber, que o conduziu a elevados cargos da República, afirma que "José de Alencar [...] pensava, no que entende particularmente com a propriedade, quase como um anarquista." Dos seus estudos sobre o assunto saiu "convicto das iniquidades acumuladas em torno desse monstro chamado propriedade" (ARARIPE JÚNIOR, 1963, p. 445.) O jurista se reporta ao livro A propriedade, editado postumamente em 1883. O leitor poderá argumentar com razão que não é um especialista em Direito ou Ciência política, assim não consegue capturar as sutilezas de uma argumentação jurídica. Em razão disso, recortam-se alguns pequenos trechos do livro; são períodos curtos, porém, definitivos, com força e valor de conceitos (ALENCAR, 1883): ${ }^{5}$

A revolução francesa consumou o que o cristianismo iniciara, a redenção da humanidade. (p. 18).

A escravidão e a pena de morte, já estão condenadas pela ciência sem apelo. Só falta que a legislação arranque-as do seu código para inumá-las nas misérias do passado. (p. 19).

Desde o primeiro instante da sua constituição a sociedade sofre o jugo ignóbil da propriedade. (p. 21); A todo direito corresponde

5 Originadas da mesma fonte (ALENCAR, 1883), as citações do bloco que segue, a fim de facilitar a leitura, virão cada uma delas seguidas pela identificação da página de que foram retiradas, posta entre parênteses. 
uma obrigação (p. 29); A jurisprudência não cura de homens, mas de proprietários. (p. 73).

Não parece que tudo isto foi ideado pela gente de beca para haver as gordas propinas do ofício? Pretenderão acaso que o direito se retempere no cadinho da justiça, onde tantas vezes se derrete o ouro dos litigantes? (p. 79).

A lei não pode criar males, a pretexto de necessidade, sob pena de mentir à sua origem, e aviltar-se. (p. 83).

Este nome servidão nos recorda que estamos ainda sob o domínio do princípio que presidiu a formação da sociedade civil; a tirania da propriedade (p. 93).

[...] isso porém o que não convém à jurisprudência, tanta simplicidade, tanta clareza e convicção, onde tem sempre reinado o caos! [...] mas ao contrário, compor uma meada jurídica, erigindo a chicana forense em lei. (p. 112).

Kant com sua poderosa inteligência não conseguiu explicar a legitimidade da propriedade. (p. 124-125).

Assim inverteu-se a significação das palavras e os princípios para manter um privilégio odioso em favor da propriedade territorial ( $\mathrm{p}$. 136); Dá vontade de exclamar como o poeta! Propriedade! És tu um nome vão! (p. 137).

A propriedade é o direito, a posse é o fato; [...] essa é a verdadeira e sã ideia que se deve formar desse ato jurídico, tão simples de sua natureza, e contudo tão complicado pela legislação civil. (p. 158).

Quem ousaria hoje sustentar que um indivíduo deve auferir vantagens de seu crime sem ver levantar-se contra ele a indignação geral? Pois a lei civil não só o diz, mas o ordena. (p. 167).

Se da monstruosa organização da propriedade civil, [...] alguma parte mínima escapou ao insulto dos seus próprios fundamentos, e não foi aluída pela contradição, o privilégio consuma a obra do absurdo. (p. 183).

Só a utilidade pública, o bem geral, pode justificar um direito superior a outro, uma hierarquia jurídica (p. 185); Aceite-se porém essa situação anômala [...], essa subversão de todo o direito, [...] em relação às considerações gerais da moral e da religião, onde a lei pretende hipocritamente se haver inspirado. (p. 192). 
Eis como a lei civil assanha a cobiça no coração humano, e transforma o credor em uma espécie de corvo ao faro da carniça! (p. 193); Porque isso simplificaria, [...] e a lei civil tem horror à simplicidade. (p. 194); A lei civil que fez do homem um mero proprietário. (p. 198).

Os trechos acima são tão somente uma amostra mínima do disponível na obra, ainda assim estão meio alongadas, sabe-se; parecem necessárias, porém, para se obter uma visada mais clara da posição do autor. Aparentemente não é possível encontrar nesses fragmentos muito do fel conservador tão apontado em Alencar. Ao contrário, fica a impressão inequívoca, se não do anarquista vislumbrado pelo leitor ilustre, no mínimo, de um crítico rigoroso dos aspectos conservadores e argentários, logo, anti-humanos, do sistema jurídico. Da mesma forma, relativamente à violência ainda mais desumanizadora e opressiva que aponta na instituição da propriedade privada. Resumidamente, nada menos que um libertário. Não se alongará citando trechos de outras obras do escritor, vale a pena, porém, mencionar escritos políticos e jurídicos como A questão do habeas corpus (1868), Sistema representativo (1868), Relatório do Ministério da Justiça (1869) e A reforma eleitoral (1874). O leitor em busca do político conservador se pasmará com a descoberta de um escritor político e doutrinário voltado para o futuro, comprometido com a democracia e a representação popular, defensor das liberdades públicas e individuais, que recusa qualquer discriminação de cor, classe social e mesmo de sexo.

\section{0 abolicionismo no teatro de Alencar}

Há uma certa divisão da crítica relativamente ao caráter abolicionista das peças $\mathbf{O}$ demônio familiar e Mãe. Alguns afirmam-na, outras a negam de maneira definitiva. Talvez convenha sondar os contemporâneos. Diz Machado de Assis em artigo publicado no Diário do Rio de Janeiro de 29 de março de 1860:

Se ainda fosse preciso inspirar ao povo o horror pela instituição do cativeiro, cremos que a representação do novo drama do sr. José de Alencar faria mais do que todos os discursos que se pudessem proferir no recinto do corpo legislativo, e isso sem que Mãe seja um drama demonstrativo e argumentador, mas pela simples impressão que produz no espírito do espectador, como convém a uma obra de arte. (ASSIS, 2008, v. 3, p. 1039-1040). 
Assim como se dá com esse crítico, como exemplares corroboradores dessa recepção, podem ser mencionados particularmente o verbete dedicado a Alencar no Dicionário popular, de Pinheiro Chagas (1876) e um artigo anônimo (na verdade, assinado L-a.) saído na Revista Popular, (julho-setembro de 1862, p. 219-221). "É um livro de propaganda abolicionista da escravidão" (BLAKE, 1899, v. 5, p. 77), disse Sacramento Blake. Araripe Júnior é outro a apontar nas duas peças o caráter de "propaganda contra a escravidão" (ARARIPE JÚNIOR, 1958, [1970] p. 175), considerando-as, porém, fracas na retratação desse mal social. Acrescente-se que o próprio autor confirma essa leitura: discursando no Parlamento, recorda a época em que escreveu essas peças como o período em que lutou contra a escravidão (ALENCAR, 1977). Avaliação oposta é encontrada em Joaquim Nabuco, mais de 15 anos depois de sua encenação, numa série de ataques corrosivos ao escritor, em que Wilson Martins vê motivações pessoais e vingativas antes de literárias (MARTINS, 1977). Anote-se, porém, que em outra parte na mesma série de artigos o autor de $\mathbf{O}$ abolicionismo já afirmara que Alencar defendia no parlamento "a escravidão que seus dramas tinham abalado" ALENCAR; NABUCO, 1965, p. 48). Aliás, nessa disputa, Alencar reitera clara e firmemente o caráter abolicionista das duas peças. Não é de se crer que o diria não fosse essa a intenção. Por que o faria?

Tome-se David Treece, como exemplo da crítica de hoje; diz ele: "Longe de implicar a defesa por Alencar de uma completa reforma estrutural, menos ainda a abolição da 'principal instituição socioeconômica do Brasil"' (TREECE, 2008, p. 238.) É difícil entender o que quer o crítico, que o escritor abolisse a escravidão? Quem o fez na época o que reivindica? Quem o faria? Alencar é, incontrastavelmente, aquele que mais avançou no trato do assunto. Suas peças cumprem, no mínimo, o nada desprezível papel de trazer à frente do palco aquilo que se queria bem escondido. Quase 20 anos depois, Nabuco ainda se sentia humilhado, sobremaneira incomodado com essa exposição. O simples fato de escrever duas peças cujos protagonistas são um preto e uma preta escravos situa o autor de $\mathbf{O}$ demônio familiar, que estreou no teatro em 1857 e Mãe, em 1860, muito à frente do seu tempo.

O Romantismo brasileiro operou com duas imagens do escravo negro. Uma delas o apresenta como abjeto gerado pela escravidão, um ser degradado, uma 
vez que essa é capaz de engendrar apenas degradação e desumanidade. ${ }^{7}$ Ou seja, a escravidão, intrinsecamente má, produz apenas o mal. Pode ser apontado como ponto extremo dessa imagem os escravos da obra As vítimas algozes, de Joaquim Manuel de Macedo. A segunda representação retrata o escravo como ser heroico e está muito bem registrada na obra de Castro Alves, alcançando seu ponto extremo, por exemplo, nos poemas de A cachoeira de Paulo Afonso, de onde se extrai descrição física do escravo Lucas: “Aquele vulto soberbo, / - Vivamente alumiado, / Atravessa o descampado, / Como uma estátua de bronze, / Do incêndio no fulvo clarão.” (ALVES, 1949, p. 1.144). À segunda dessas figurações corresponde a Joana de A mãe; à figuração negativa corresponde o Pedro de $\mathbf{O}$ demônio familiar. Diferentemente de Macedo, que povoou seu livro de verdadeiros monstros, Alencar apresenta, como face negativa encarnada, um moleque vivo, esperto e ingênuo uma criança levada. Joana, por sua vez, é uma mãe extremosa e abnegada, disposta a tudo sacrificar e tudo sacrificando em favor do filho. Verdadeira encarnação da maternidade, não é casual que o autor tenha mandado imprimir a peça com uma longa e apaixonada dedicatória à mãe na página de abertura.

Ora, não podemos decidir como uma época deve recepcionar sua literatura. As duas peças de Alencar foram recebidas pelos contemporâneos como obras abolicionistas e com tal intento seu autor declara tê-las escrito. Além de demandar coragem e independências - características difíceis de se negarem a esse autor - e demonstrar uma grande simpatia humana pelo escravo. Seria o caso de se perguntar a quem tem dúvidas sobre o progressismo do teatro de Alencar, quantos autores, contando de então até hoje, escreveram duas peças teatrais com protagonistas negras. Também na crítica mais próxima dos dias de hoje, há vozes autorizadas entre os que enxergam o que parece transparente nas duas peças: o seu compromisso com a abolição. Destaque-se, como um exemplo, Raymond Sayers (1958, p. 365) a opinar que "em suas peças a nota antiescravista é clara e incisiva". Segundo esse crítico, "não há dúvida de que, em duas de suas peças, $O$ demônio familiar e a Mãe, ele manifesta-se contra a escravidão" (SAYERS, 1958, p. 276). Também João Roberto Faria (1987), em José de Alencar e o teatro, sabe reconhecer-lhes esse caráter, como já o fizera Brito Broca (1979) em Românticos, ultrarromânticos e pré-românticos.

7 Essa imagem da escravidão transita pela literatura e perpassa a sociedade, como se pode ver em Ilmar de Mattos: "Brutalidade, vaidade, egoísmo, doenças, paixões, desordem, sexualidade desregrada e muitos outros males e desvios eram atribuídos à presença do escravo no seio da família branca citadina." (MATTOS, 1987, p. 242-243). 


\section{A escravidão nos romances}

Aqui seria importante também registrar que a dependência do senhor pela intermediação do escravo apontada por Antonil nos idos do século 18 se prolonga pela história, atravessa Colônia e Império, apresentando-se contemporânea de Alencar, por este foi devidamente criticada. No livro $\mathbf{O}$ tronco do ipê, aparece uma personagem - Adélia - incapaz até de saborear uma fruta sem o concurso dos escravos que a servem:

Quando o pajem Martinho lhe trazia uma goiaba ou figo, ela segurando-a na pontinha dos dedos enluvados, voltava-se para a mucama:

- Fará mal, Felícia?

- Deixe ver, Iaiá.

A Felícia tomava então a fruta, que cheirava e abria ao meio; comendo uma banda dava a outra a Adélia:

- Pode comer, iaiá! Está muito gostosa. (ALENCAR, 1951, p. 49).

Assim como a iaiá, o latifúndio e a agricultura, herdados do período colonial, também não se movem sem o concurso do escravo. Sua importância é reconhecida desde 1822, quando da Independência, simbolizada nas armas nacionais então instituídas que traziam um ramo de café e outro de tabaco. Aliás, cumpre observar que os ramos lá permaneceram pela República adentro, uma vez que o 15 de novembro de 1899 nada mudaria relativamente à importância econômica da lavoura que permaneceria a força dominante pelo menos até os anos de 1930. Aliás, deve ser anotado que o poder político do campo só cresceu com a República, uma vez que no período imperial, dado o tipo de organização estatal que se desenvolveu no país, havia maior afastamento e autonomia do mundo da política face ao mundo econômico. Sobre a política, porém, não se alongará nesta parte. Convém, mais uma vez, dar a voz ao romancista, que é quem mais interessa, recortando um trecho do mesmo livro em que abolicionismo e escravismo se confrontam num breve debate de ideias:

O conselheiro, que não perdia ocasião de angariar as simpatias dos fazendeiros de quem dependia a sua reeleição, fez um discurso a respeito do tráfico.

- Eu queria, disse ele concluindo, que os filantropos ingleses assistissem a este espetáculo, para terem o desmentido formal de 
suas declamações, e verem que o proletário de Londres não tem os cômodos e gozos do nosso escravo.

- É exato, disse Mário. A miséria das classes pobres na Europa é tal, que em comparação com elas o escravo do Brasil deve considerar-se abastado. Mas isso não justifica o tráfico, o repulsivo mercado de carne humana.

— Utopias sentimentais! ...

- Perdão; eu compreendo que nos primeiros tempos da colonização o tráfico fosse uma necessidade indeclinável. A sociedade humana não é uma república de Platão, mas um ente movido pelos instintos e paixões dos homens de que se compõe. Eram precisos braços para explorar a riqueza da colônia; o europeu não resistia; o índio não sujeitara-se; compraram o negro; mais tarde o tráfico tornou-se um luxo, e produziu um mal incalculável porque radicou no país a instituição da escravatura. (ALENCAR, 1951, p. 237).

Eis aí o que diz Mário, o herói da narrativa, sem dúvida alguma a voz mais aderente à voz autoral, chegando mesmo alguns críticos a apontarem, na personagem, um alter ego do escritor. ${ }^{8}$ Note-se a desconstrução moral do discurso - que foi de Alencar (2009) nas Cartas de Erasmo ${ }^{9}$ - comparador das condições do proletário europeu ao escravo brasileiro. Resumindo: a escravidão é intrinsecamente má. Esse livro foi publicado em 1872, na plena maturidade e vigor intelectual do seu autor, parece, portanto, boa providência tomá-lo como representativo do seu pensamento. Se é possível dizer que o ficcionista firmou uma posição ante o escravismo, ela está aí expressa. E junto, enfatiza-se, uma cristalina mudança de posição, evoluindo da defesa política da escravidão no escrito de 1867 à sua estrita condenação no romance saído cinco anos depois.

Cabe, porém, conforme já se disse mais de uma vez, mais que negar ou afirmar a condição conservadora ou renovadora, escravocrata ou antiescravagista de Alencar, que não se simplifique uma personalidade tão complexa. Se é possível encontrar nos seus discursos e atos na esfera da política alguns de que se pode - e deve, muitas vezes - apontar a condição lenientes com o escravismo ou conservadorismo, há também tantos outros que apontam no sentido exatamente oposto. Na obra literária não parece haver daqueles textos, sua posição é antiescravagista. A

8 Eugênio Gomes (1958, p. 34) aponta esse Mário como “o mais expressivo duplo do próprio romancista".

9 "O velho mundo tem em seu próprio seio um cancro que lhe rói as entranhas: é o pauperismo. [...] A liberdade é o meio, um direito; o fim é a felicidade, e desta o escravo brasileiro tem um quinhão, que não é dado sonhar ao proletário europeu. De que serve ao pária da civilização a liberdade que a lei consagra por escárnio, quando a sociedade a anula fatalmente por sua organização, criando a opressão da miséria?" (ALENCAR, 2009, p. 324). 
projeção pública do escritor foi relativamente curta, de 1854 a 1877; porém 23 ou 24 anos são um longo período de uma vida, particularmente viveu breves 48 anos, de que são a metade, e praticamente a totalidade da sua vida adulta e independente. Imaginar que esse ser durante esse tempo tenha permanecido igual, não mudando nunca seria subestimar inteligência e sensibilidade tão agudas.

A verdade parece ser que a atuação política de Alencar era por demais exigente e complexa para um tempo caracterizado tanto pela fluidez quanto pela imprecisa definição das posições políticas, em que a ideia de mudança não alcançava além da perspectiva de chegada do próprio grupo ao poder. É esse o escritor que se tornou canônico, é esse o ser humano que vale a pena buscar por trás das letras, não a figura unidimensional que muitas vezes apresentam os estudiosos. Alencar oscilou, mudou de posição, às vezes mesmo bruscamente, foi homem do seu tempo e artista sensível e aberto para a posteridade; nessa condição pugnou pela permanência do que julgava correto e mudança do que devia ser mudado. Suas antenas souberam captar tanto os medos e as angústias de uma sociedade que começava a mudar e se assustava com isso como os mais generosos anseios dos sonhadores.

\title{
Questions about José de Alencar's conservatism
}

\begin{abstract}
It seems there is no doubt about how conservative José de Alencar was for the literary critics. Registers of his time confirm the author was in favor of monarchy and endorsed slavery. This paper intends to examine how precise these facts are by reviewing the author's career as well as his fictional and non-fictional exercise. The idea is to introduce some questions and doubts about the theme, apparently an excess of certainty and a lack of debate prevails.
\end{abstract}

Keywords: José de Alencar. Conservativism. Slavery and literature.

\section{Referências}

ALENCAR, José de. Escritos políticos. Brasília: Senado Federal, 2011.

ALENCAR, José de. Cartas de Erasmo. Organização de José Murilo de Carvalho. Rio de Janeiro: ABL, 2009. 
ALENCAR, José de. Discursos parlamentares. Brasília: Câmara dos Deputados, 1977.

ALENCAR, José de; NABUCO, Joaquim. A polêmica Alencar-Nabuco. Organização de Afrânio Coutinho. Rio de Janeiro: Tempo Brasileiro, 1965.

ALENCAR, José de. O tronco do ipê. Rio de Janeiro: José Olympio, 1951.

ALENCAR, José de. A propriedade. Rio de Janeiro: B. L. Garnier, 1883.

ALENCAR, José de. Reforma eleitoral. Rio de Janeiro: J. Villeneuve, 1874.

ALENCAR, José. Literatura dramática. O demônio familiar. Revista Popular, Rio de Janeiro, ano IV, tomo XV, p. 158-165; 219-227, jul./set. 1862.

ALVES, Castro. Poesias completas. In: RAMOS, Frederico José da Silva. (Org.). Grandes poetas românticos do Brasil. São Paulo: LEP, 1949. p. 1.036-1.157.

ANTONIL, André João. Cultura e opulência do Brasil. 2. ed. São Paulo: Melhoramentos, 1976.

ARARIPE JUNIOR. José de Alencar. In: ARARIPE JÚNIOR. Obra crítica. Organização de Afrânio Coutinho. 5 v. Rio de Janeiro: Casa de Rui Barbosa, 19581970. v. 1. p. 129-258.

ARARIPE JÚNIOR. A propriedade. In: ARARIPE JUNIOR. Obra crítica. Organização de Afrânio Coutinho. 5 v. Rio de Janeiro: Casa de Rui Barbosa, 1963. v. 3. p. 445-450.

BINZER, Ina von. (pseud.: Ulla von Eck). Os meus romanos: alegrias e tristezas de uma educadora alemã no Brasil. Tradução de Alice Rossi e Luisita da Gama Cerqueira. 6. ed. Rio de Janeiro: Paz e Terra, 1994.

BARBOSA, Francisco de Assis. José de Alencar jornalista. Boletim Bibliográfico - Alencar: Cem Anos Depois, São Paulo, Biblioteca Mário de Andrade, v. 38, n. 3-4, p. 53-63, jul./dez. 1977.

BLAKE, Sacramento. Dicionário bibliográfico brasileiro. 7 v. Rio de Janeiro: Imprensa Nacional, 1899. v. 5. p. 74-81.

BROCA, Brito. Românticos, ultrarromânticos e pré-românticos: vida literária e Romantismo no Brasil. São Paulo: Polis, 1979.

CARVALHO, José Murilo. Teatro de sombras: a política imperial. Rio de Janeiro: Vértice, 1988.

CARVALHO, José Murilo de. A construção da ordem: a elite política imperial. Brasília: Ed. Universidade de Brasília, 1981. 
CHAGAS, Manuel Pinheiro. (dir.). Dicionário popular: v. 1. Lisboa: Lallemant Frères, 1876.

FAORO, Raymundo. Os donos do poder. 6. ed. 2 v. Porto Alegre: Globo, 1984. v. 2 .

FARIA, João Roberto. José de Alencar e o teatro. São Paulo: Perspectiva/Edusp, 1987.

FURTADO, Celso. Formação econômica do Brasil. 27. ed. São Paulo: Nacional, 2000.

GARBUGLIO, José Carlos. Senhora, à imagem do senhor. In: ALENCAR, José de. Senhora. ed. crit. de José Carlos Garbuglio. Rio de Janeiro/São Paulo: LTC/ Edusp, 1979. p. 271-277.

GOMES, Eugênio. Aspectos do romance brasileiro. Salvador: Progresso, 1958.

MACEDO, Joaquim Manuel de. As vítimas algozes: quadros da escravidão. Organização de Rachel Teixeira Valença. São Paulo: Scipione, 1991.

MARTINS, Wilson. História da inteligência brasileira: 7 v. São Paulo: Cultrix/ Edusp, 1977. v. 3.

MATTOS, Ilmar Rohloff de. O tempo saquarema. São Paulo: Hucitec, 1987.

MAUA, Visconde de (Irineu Evangelista de Souza). Autobiografia: exposição aos credores e ao público. Rio de Janeiro: Ediouro, 1964.

MERLINO, Mário. Brasil y la novela en el siglo XIX. In: MERLINO, Mário (Org.). Las mejores novelas de la literatura universal: novela brasileña. Madrid: Cupsa, 1984. v. XXI, p. IX-XXXIV.

NABUCO, Joaquim. O abolicionismo. São Paulo: Publifolha, 2000.

NABUCO, Joaquim. Minha formação. Brasília: Ed. Universidade de Brasília, 1963.

PEREIRA, Astrojildo. Interpretações. Rio de Janeiro: Casa do Estudante do Brasil, 1944.

RIBEIRO, Júlio. Cartas sertanejas/Procellarias. São Paulo: Fundap/Imprensa Oficial, 2007.

RODRIGUES, José Honório. A lei do ventre livre: primeiro centenário. Carta Mensal, Rio de Janeiro, Conselho Técnico da Confederação Nacional do Comércio, v. XVI, n. 204, p. 3-15, mar. 1972. 
SANTIAGO, Silviano. Ora (direis) puxar conversa! Belo Horizonte: Ed. UFMG, 2006.

SAYERS, Raymond S. O negro na literatura brasileira. Tradução de Antônio Houaiss. Rio de Jenrio: O Cruzeiro, 1958.

TREECE, David. Exilados, aliados, rebeldes. Tradução de Fábio Fonseca de Melo. São Paulo: Edusp, 2008.

URICOECHEA, Fernando. O minotauro imperial. Rio de Janeiro: Difel, 1978.

VERÍSSIMO, José. Estudos de literatura brasileira. $3^{\text {a }}$ série. Belo Horizonte: Itatiaia, 1977.

VIANA, Oliveira. O ocaso do Império. 3. ed. Rio de Janeiro: Academia Brasileira de Letras, 2006.

VIANA, Oliveira. Populações meridionais do Brasil. Brasília: Senado Federal, 2005.

Recebido em 21/06/ 2016

Aceito em 27/09/ 2016 